\title{
SISTEM PENDUKUNG KEPUTUSAN PEMILIHAN MAHASISWA PENERIMA BEASISWA LOKAL MANAJEMEN INFORMATIKA UNMER MADIUN MENGGUNAKAN WEIGHTED PRODUCT
}

\author{
Pradityo Utomo*1, Arief Budiman² \\ ${ }^{1,2}$ Program Studi Manajemen Informatika, Fakultas Teknik, UNMER, Madiun \\ e-mail: *1pradityo@unmer-madiun.ac.id, ${ }^{2}$ arief@unmer-madiun.ac.id
}

\begin{abstract}
Abstrak-Beasiswa merupakan dana bantuan yang diperuntukkan bagi anak yang berprestasi atau kurang mampu. Universitas Merdeka Madiun (Unmer Madiun) adalah salah satu Perguruan Tinggi Swasta di Jawa Timur yang memiliki program beasiswa lokal pada program studinya. Salah satu program studi di Unmer Madiun yang memiliki program beasiswa lokal adalah Manajemen Informatika. Beasiswa lokal diperuntukkan khusus mahasiswa Manajemen Informatika yang memiliki prestasi di bidang akademik. Untuk pemilihan mahasiswa yang menerima harus memenuhi beberapa kriteria, antara lain mahasiswa harus memiliki IPK di atas 3,00 , mahasiswa harus pernah menulis karya ilmiah, dan mahasiswa harus aktif dalam organisasi. Sistem Pendukung Keputusan (SPK) yang berbasis teknologi informasi dapat digunakan untuk membantu pemilihan mahasiswa yang berhak menerima beasiswa lokal, Kriteria yang digunakan untuk pemilihan juga diterapkan dalam SPK pemilihan mahasiswa penerima beasiswa lokal. Untuk metode yang digunakan Sistem Pendukung Keputusan adalah Weighted Product. Sistem Pendukung Keputusan dibangun menggunakan metode Build and Fix, yang dianggap mampu membangun sistem secara cepat. Pada penelitian sistem pendukung keputusan pemilihan mahasiswa penerima beasiswa lokal program studi Manajemen Informatika, didapatkan hasil tingkat keberhasilan sistem sebesar 100\% dengan pengujian Black Box. Berdasarkan keberhasilan yang dicapai, sistem dapat digunakan dalam membantu pemilihan mahasiswa yang berhak menerima beasiswa lokal.
\end{abstract}

Kata kunci-Beasiswa Lokal, Weighted Product, Sistem Pendukung Keputusan

\section{PENDAHULUAN}

Universitas Merdeka Madiun (UNMER Madiun) memiliki lima Fakultas antara lain Fakultas Hukum, Fakultas Ilmu Sosial dan Ilmu Politik, Fakultas Ekonomi, Fakultas Pertanian, dan Fakultas Teknik. Jumlah mahasiswa yang dimiliki pada setiap Program Studi juga cukup banyak. Karena jumlah mahasiswa yang cukup banyak, sehingga kompetisi untuk mendapatkan besiswa juga lebih ketat. Mahasiswa selalu berkompetisi untuk mendapatkan beasiswa pada setiap tahunnya. Jumlah beasiswa yang tersedia tidak sebanding dengan jumlah mahasiswa yang berprestasi di UNMER Madiun. Untuk itu, Program Studi (Prodi) D3 Manajemen Informatika yang berada di bawah Fakultas Teknik mengadakan beasiswa lokal prodi. Dengan adanya beasiswa lokal prodi D3 Manajemen Informatika, diharapkan dapat membantu mahasiswa berprestasi untuk mendapatkan bantuan biaya kuliah. Dimana beasiswa ditujukan hanya untuk mahasiswa D3 Manajemen Informatika. Beasiswa berlaku untuk dua orang dalam dua semester. Bantuan yang diberikan adalah berupa biaya SPP semester. Tetapi untuk mendapatkan beasiswa, mahasiswa harus berkompetisi dengan memenuhi beberapa persyaratan yang sudah ditetapkan oleh Prodi. Beberapa diantaranya adalah nilai IPK minimum 3,00 , keaktifan mengikuti organisasi, dan keikutsertaan dalam penulisan karya ilmiah. Untuk Keaktifan organisasi tidak dibatasi organisasi yang diikuti, baik organisasi tingkat Prodi, tingkat Fakultas, maupun Universitas. Sedangkat untuk keikutsertaan dalam penulisan karya ilmiah, dapat berupa Lomba Karya Ilmiah ataupun keterlibatan dalam penulisan jurnal baik nasional maupun internasional.
Program Studi dengan menggunakan parameter penilaian tersebut sering mengalami kebingungan dalam melakukan pemilihan mahasiswa penerima beasiswa. Karena setiap karakteristik penilaian memiliki poin tersendiri.

Pada penelitian ini akan dibahas sebuah sistem yang dapat membantu pengelola Program Studi dalam melakukan pemilihan mahasiswa penerima beasiswa lokal D3 Manejemen Informatika. Sistem yang akan dibuat adalah Sistem Pendukung Keputusan menggunakan metode Weighted Product.Dengan menggunakan salah satu metode sistem pendukung keputusan, diharapkan pengelola program studi dapat terbantu untuk memilih mahasiswa penerima beasiswa. Weighted Product merupakan salah satu metode sistem pendukung keputusan yang cukup cepat dalam melakukan komputasi. Karena alur perhitungan komputasi tidak terlalu banyak. Dimulai penentuan kriteria, pembobotan alternatif dan nilai, kemudian dicari nilai vektornya. Sehingga metode Weigthted Product dianggap sesuai untuk mengatasi kasus yang dialami pengelola Program Studi dalam melakukan pemilihan penerima beasiswa lokal D3 Manajemen Informatika.

Beberapa penelitian terkait yang digunakan untuk mendukung penelitian ini antara lain penelitian yang dilakukan Nurjannah,dkk pada tahun 2015. Pada penelitian tersebut, metode Weighted Product (WP) digunakan untuk membuat sistem pendukung keputusan dalam pembelian motor. Dimana sistem memberikan informasi rekomendasi pembelian sepeda motor berdasarkan kriteria. Kriteria yang digunakan antara lain harga, teknologi, mesin, dan model [1].

Pada tahun selanjutnya, salah satu penelitian yang 
dibuat menggunakan metode WP adalah untuk memilih lokasi lahan pemakaman bagi umat muslim. Penelitian tersebut memilih menggunakan metode WP, karena perhitungannya lebih singkat dibandingkan metode lainnya. Hasil yang dihasilkan berupa lokasi lahan, dengan ditampilkan visualisasi dari google maps [2]. Pada tahun yang sama juga dilakukan penelitian terkait metode WP dilakukan oleh Yoni dan Mustafidah. Metode WP digunakan untuk memilih lulusan terbaik di Universitas Muhammadiyah Purwokerto dengan menggunakan kriteria yaitu IPK, masa studi, tidak ada nilai $\mathrm{D}$, dan nilai 1 maksimal $\mathrm{C}$. Untuk metode pengembangan sistem yang digunakan adalah waterfall [3]. Penelitian lain yang dilakukan pada tahun 2016 dilakukan oleh Khairina dkk. Pada penelitian tersebut dibuat aplikasi untuk memilih smartphone android menggunakan metode WP. Kriteria-kriteria yang digunakan untuk membuat aplikasi tersebut dari hasil kuisioner. Kriteria yang digunakan antara lain harga, memori internal, RAM, kamera, dan kapasitas baterai. Sedangkan untuk hasil yang didapat adalah rekomendasi pertimbangan kepada pengguna dalam memilih smartphone [4][5]. Pemanfaatan metode WP juga digunakan untuk Sistem Pendukung Keputusan dalam memilih Calon Ketua BEM STMIK Banjarbaru.Untuk kriteria yang digunakan berupa Frekuensi keikutsertaan LDK, IPK, Visi, Misi, Prestasi Non Akademik, dan Dukungan awal. Keluaran yang dihasilkan sistem berupa dua calon Ketua BEM MHS8 dan MHS13 [6]. Sistem Pendukung Keputusan juga dapat dibuat berupa Website dengan menerapkan metode WP. Syafitri dkk telah menerapkan metode WP dalam membuat Sistem Pendukung Keputusan untuk memilih Laptop berbasis web[7]. Kriteria-kriteria yang digunakan diantaranya harga, RAM, processor, harddisk, dan VGA Hasil yang diberikan oleh sistem berupa saran pembelian laptop. Tingkat akurasi keberhasilan sistem sebesar 100\% [8].

Tahun 2017 juga terdapat beberapa penelitian terkait penerapan metode WP. Salah satunya dilakukan oleh Jalil dkk dengan membuat Sistem Pendukung Keputusan pemberian kredit kepada BMT Mu'amalah Sejahtera Kendari. Sistem diuji dengan membandingkan perhitungan secara manual[9]. Output yang dihasilkan sistem adalah saran kepada pimpinan BMT Mu'amalah Sejahtera Kendari dalam memilih penerima kredit [10]. Penelitian lain pada 2017 dilakukan oleh Mustafidah dan Hadyan yang membuat Sistem Pendukung Keputusan dengan metode WP untuk pemilihan mahasiswa berprestasi di Universitas Muhammadiyah Purwokerto. Kriteria-kriteria yang digunakan dalam pembuatan sistem antara lain IPK, karya tulis, prestasi unggulan, dan bahasa inggris. Sistem yang telah selesai dibangun diterapkan secara riil di Universitas Muhammadiyah Purwokerto [11].
II. LANDASAN TEORI

Weighted Product (WP) merupakan metode Sistem Pendukung Keputusan yang alur perhitungannya cukup singkat. Dimana WP menggunakan perkalian atribut, dimana atribut rating terlebih dahulu dipangkatkan dengan bobot yang disebut normalisasi bobot menggunakan rumus 1 [1][12].

$$
W j=\frac{w j}{\sum w j} \text {. }
$$

Selanjutnya dilakukan preferensi untuk perhitungan alternatif menggunakan rumus 2 .

$$
S i=\prod_{j=1}^{n} X i j^{W j} \text {. }
$$

Setelah menghitung $\mathrm{W}$ dan $\mathrm{S}$, kemudian dilakukan perangkingan terakhir dengan menghitung $\mathrm{V}$ menggunakan rumus 3 .

$$
V i=\frac{\prod_{j=1}^{n} x_{i j} W_{j}}{\prod_{i=1}^{m}\left(x_{j}\right)^{W j}} .
$$

Keterangan :

$\mathrm{W}:$ Bobot

i : Alternatif

$\mathrm{j}:$ Atribut

$X$ : Rating alternatif per atribut

$\mathrm{S}$ : Hasil normalisasi keputusan

$\mathrm{V}:$ Hasil preferensi alternatif

\section{METODE}

Pada penelitian ini memilih tempat penelitian di Program Studi Manajemen Informatika UNMER Madiun. Dimana prodi tersebut memiliki program beasiswa lokal khusus untuk mahasiswa lokal prodi Manajemen Informatika. Untuk tahapan metode penelitian ini dapat dilihat pada Bagan Alir Penelitian, dimana terdapat beberapa tahapan yang menggunakan metode pengembangan sistem dan metode pengujian sistem. Untuk setiap tahapan penelitian dapat dilihat pada Gambar 1.

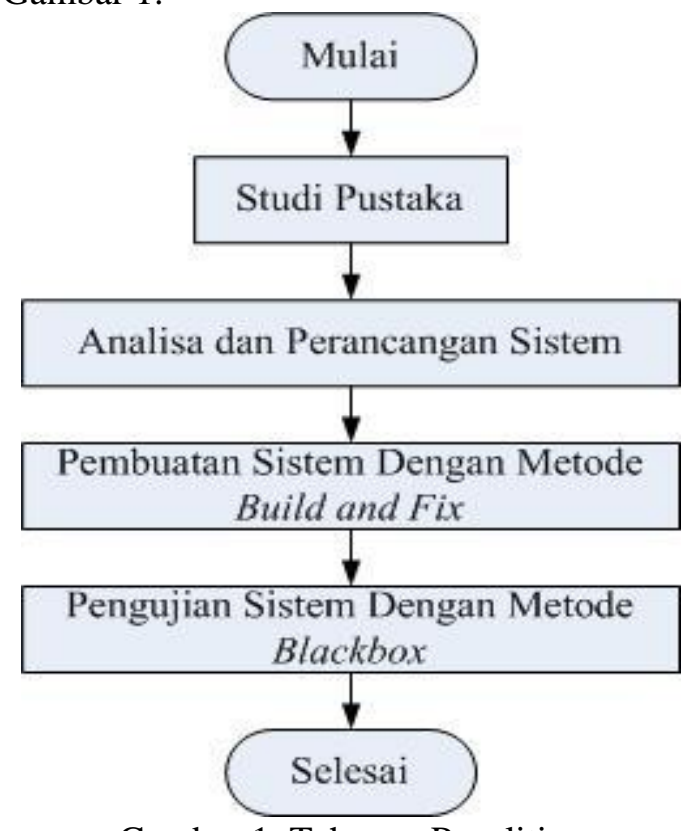

Gambar 1. Tahapan Penelitian 


\section{HASIL}

Pada Gambar 1 telah ditampilkan tahapan-tahapan dari penelitian ini. Dimulai dari Studi Pustaka, Analisa dan Perancangan Sistem, Pembuatan Sistem Dengan Metode Build and Fix, Pengujian Sistem Dengan Metode Blackbox, kemudian selesai. Adapun penjelasan setiap tahapannya adalah sebagai berikut :

1. Studi Pustaka

Pada tahapan Studi Pustaka akan dilakukan pengumpulan dan pembelajaran terkait pustaka, literatur, maupun penelitian terkait. Pembelajaran pustaka dikhususkan pada penelitian-penelitian terdahulu dan teori-teori yang terkait dengan penelitian ini.

2. Analisa dan Perancangan Sistem

Analisa dan perancangan sistem dibutuhkan untuk menganalisa terlebih dahulu kebutuhan dari sistem, yang selanjutnya dilakukan perancangan sebelum diimplementasikan ke dalam sebuah sistem/program.

3. Pembuatan Sistem Dengan Metode Build and Fix Metode yang digunakan untuk pembuatan sistem adalah Build and Fix. Karena sistem yang tidak begitu kompleks, dan harus selesai dalam waktu cepat, sehingga metode Build and Fix dianggap cocok untuk menyelesaikan Sistem Pendukung Keputusan ini. Adapun tahapan dari Build and Fix dapat dilihat pada Gambar 2.

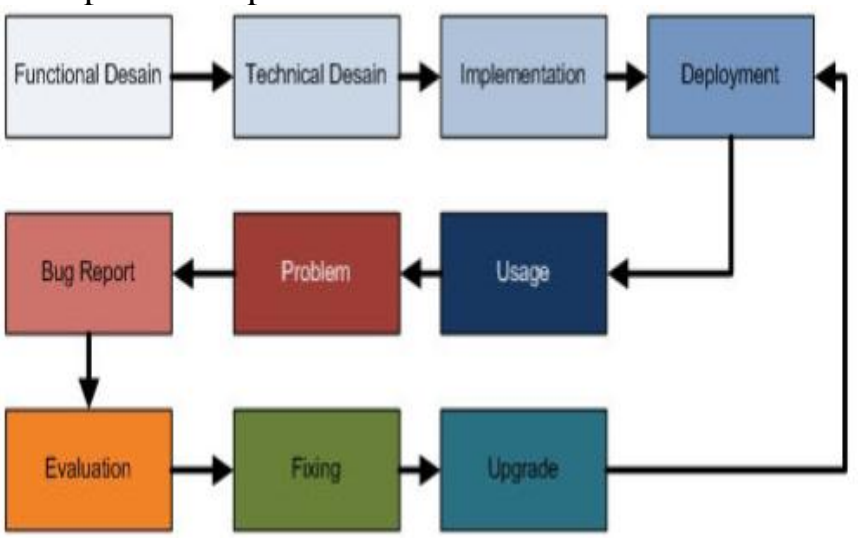

Gambar 2. Metode Build and Fix [13]

Pada Gambar 2 dijelaskan alur dari metode Build and Fix yang dimulai pembangunan sistem, yang selanjutnya disesuaikan dahulu dengan keinginan user. Jika tidak sesuai dengan keinginan user, maka pembuat harus memperbaiki. Untuk tahapan setelah sistem dianggap selesai, kemudian pembuat sistem masih harus bertanggung jawab jika terjadi eror di kemudian hari. Tanggung jawab pembuat sistem dianggap selesai jika user sudah tidak menggunakannya.

4. Pengujian Sistem Dengan Metode Blackbox

Pada tahapan pengujian, sistem akan diarahkan ke pengujian fungsionalitas. Dimana sistem diuji menggunakan metode blackbox untuk mengetahui ketepatan dai fungsi-fungsi yang disediakan dalam sistem.
Pada bagian awal pembahasan hasil, dibahas perancangan sistem menggunakan Use Case Diagram yang ditunjukkan pada Gambar 3.

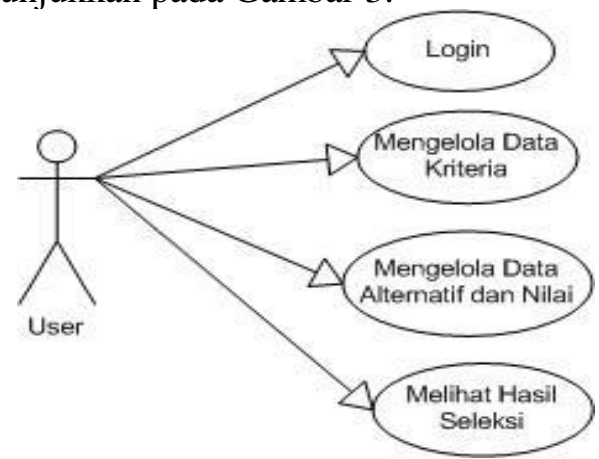

Gambar 3. Use Case Diagram Sistem

Gambar 3 telah disajikan perancangan sistem yang meliputi proses login, pengelolaan data kriteria, pengelolaan data alternatif dan nilai, dan juga user dapat melihat hasil seleksi. Berdasarkan perancangan tersebut, dibuat sebuah sistem pendukung keputusan yang dapat membantu dalam memilih penerima beasiswa lolal prodi Manajemen Informatika UNMER Madiun. Dari use case login, dapat diimplementasikan pada sistem seperti pada Gambar 4.

SPV PENERIMA BEASISWA LOKAL PRODI MANAJEMEN INFORMATIKA

UN MER MADIUN

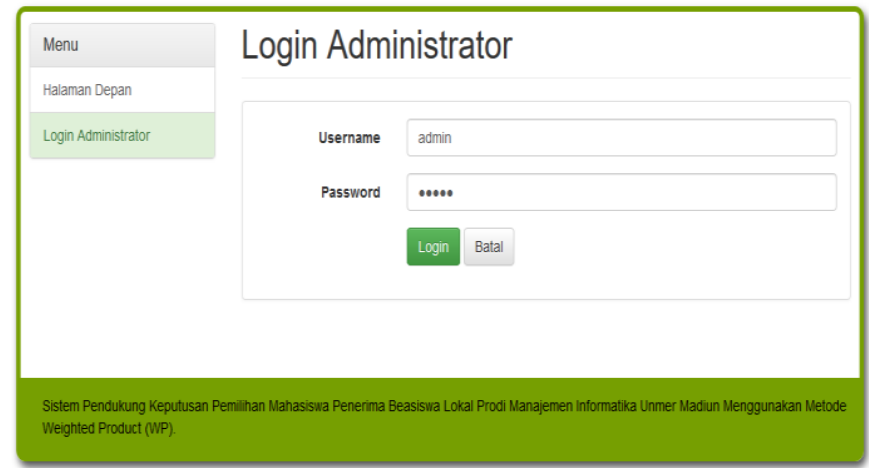

Gambar 4. User Login

User dapat melakukan login dengan mengisikan username dan password untuk dapat masuk ke dalam sistem. Jika username dan password sesuai, maka user dapat masuk beranda sistem seperti yang ditunjukkan pada Gambar 5. 


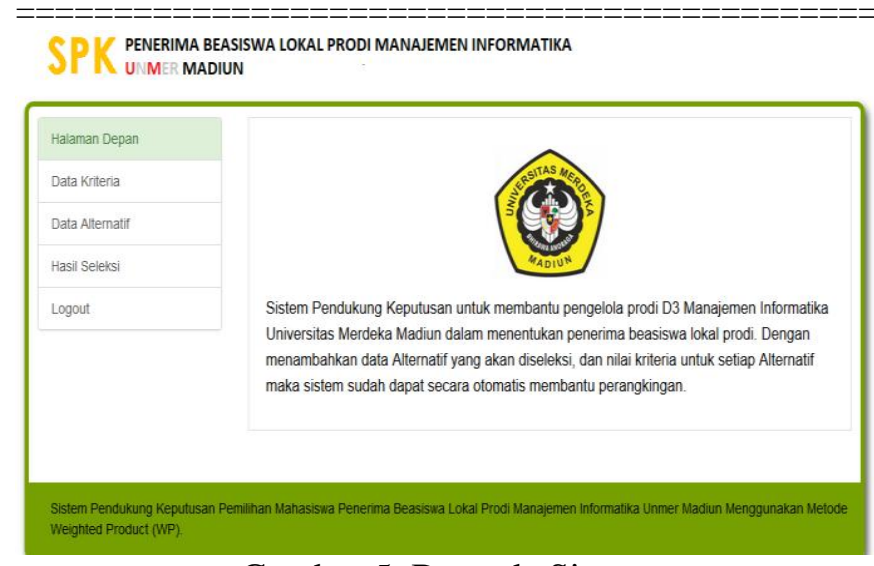

Gambar 5. Beranda Sistem

Di Gambar 5 telah ditampilkan beranda sistem, dimana menu-menu yang tersedia yaitu data kriteria, data alternatif, dan hasil seleksi. Pada halaman data kriteria, user dapat melakukan pengelolaan data kritera. User dapat menambahkan data baru, mengedit, dan menghapus data. User dapat memberikan nilai bobot untuk setiap kriteria. Untuk tampilan data kriteria dapat dilihat pada Gambar 6.

SPK PENERIMA BEASISWA LOKAL PRODI MANAJEMEN INFORMATIKA

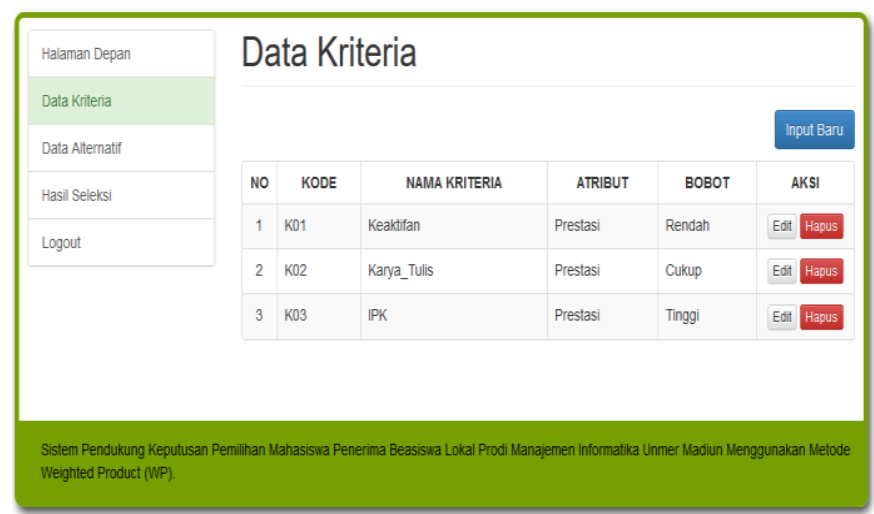

Gambar 6. Halaman Data Kriteria

Dimana terdapat tiga kriteria untuk menentukan penerima beasiswa, diantaranya keaktifan, karya tulis, dan IPK. Untuk keterangan masing-masing nilai bobotnya dapat dilihat pada Tabel 1 .

Tabel 1. Data Kriteria

\begin{tabular}{|c|c|c|c|c|}
\hline No & $\begin{array}{c}\text { Nama } \\
\text { Kriteria }\end{array}$ & Atribut & Bobot & $\begin{array}{c}\text { Nilai } \\
\text { Bobot }\end{array}$ \\
\hline 1 & $\begin{array}{c}\text { Keaktifan } \\
\text { Organisasi }\end{array}$ & Prestasi & Rendah & 1 \\
\hline 2 & Karya Tulis & Prestasi & Cukup & 2 \\
\hline 3 & IPK & Prestasi & Tinggi & 3 \\
\hline
\end{tabular}

Selain menu Data Kriteria, terdapat menu Data Alternatif. Pada menu tersebut, ditampilkan data alternatif dan nilai. Untuk data alternatif yang berisi nilai dapat dilihat pada Tabel 2 .
Tabel 4.2. Data Alternatif dan Nilai

\begin{tabular}{|c|c|c|c|c|}
\hline No & $\begin{array}{c}\text { Nama } \\
\text { Alternatif }\end{array}$ & Keaktifan & $\begin{array}{c}\text { Karya } \\
\text { Tulis }\end{array}$ & IPK \\
\hline 1 & M. Riski & 90 & 80 & 3.5 \\
\hline 2 & Shania & 75 & 90 & 3.8 \\
\hline 3 & Anggun & 90 & 70 & 3.3 \\
\hline 4 & Oktadear & 70 & 80 & 3.4 \\
\hline 5 & Bayu & 90 & 75 & 3.5 \\
\hline
\end{tabular}

Berdasarkan Tabel 2 dapat diimplementasikan ke dalam sistem seperti yang ditunjukkan pada Gambar 7. User dapat menambahkan, mengedit,dan menghapus data alternatif, dalam hal ini data alternatif berisi nama mahasiswa calon penerima beasiswa lokal.

SPK PENERIMA BEASISWA LOKAL PRODI MANAJEMEN INFORMATIKA

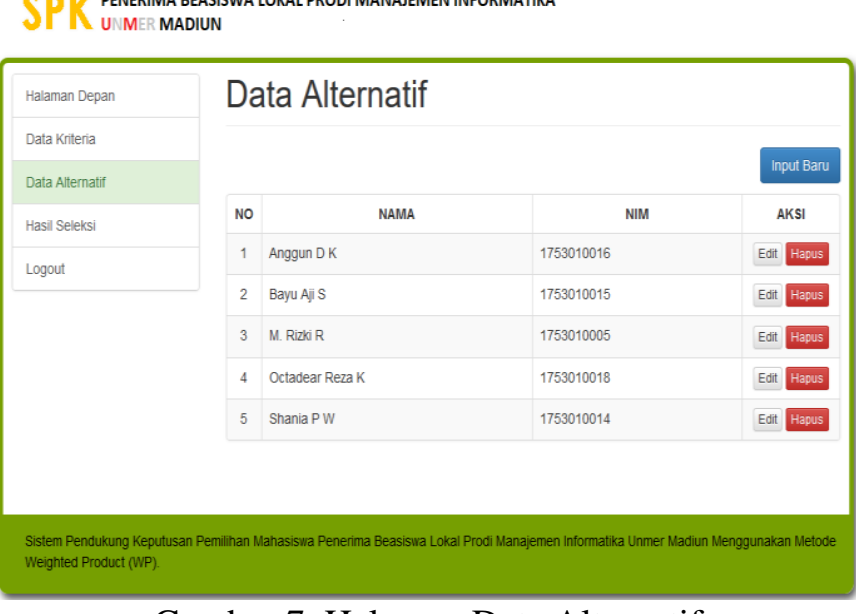

Gambar 7. Halaman Data Alternatif

Setelah dilakukan input data kriteria dan alternatif, selanjutnya dilakukan perangkingan. Pada halaman hasil seleksi disajikan nilai akhir penyeleksian dari sistem pendukung keputusan, untuk tampilannya dapat dilihat pada Gambar 8. 


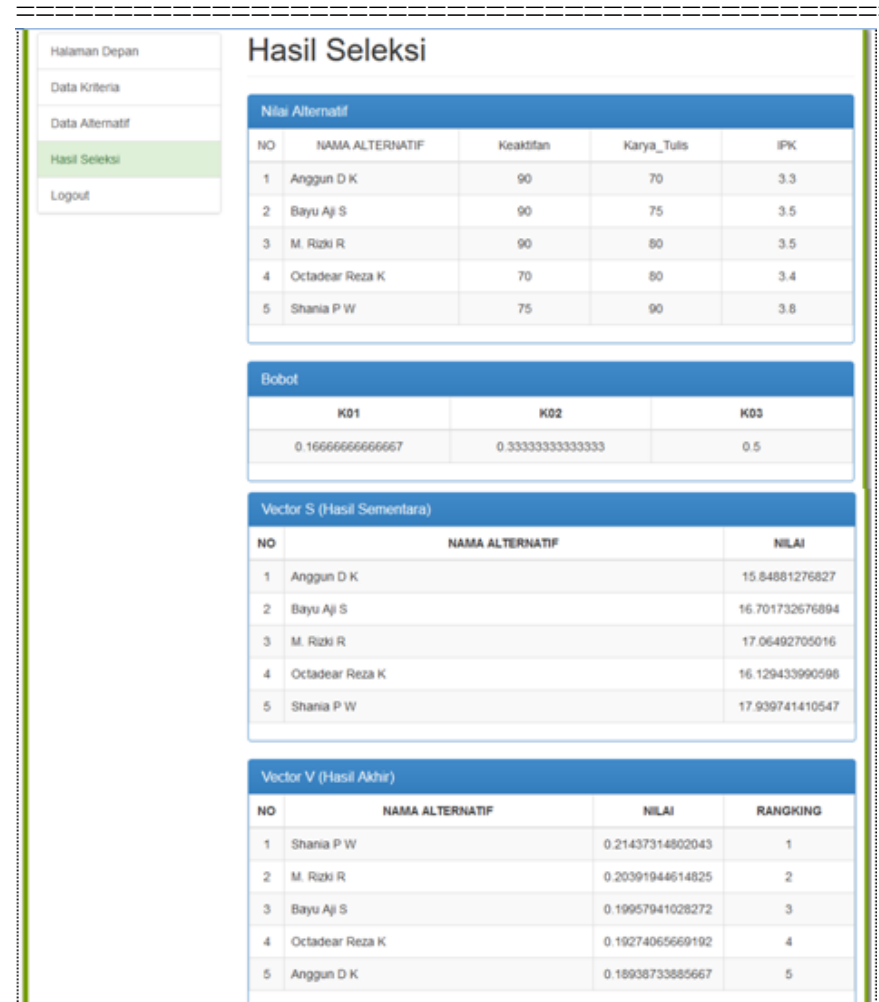

Gambar 8. Halaman Hasil Seleksi

Berdasarkan Gambar 8, untuk memperbaiki nilai bobot dapat dilakukan dengan perhitungan $\mathrm{W}$ menggunakan rumus 1 .

$$
\begin{aligned}
& W 1=\frac{1}{1+2+3}=0.16666667 \\
& W 2=\frac{2}{1+2+3}=0.33333333 \\
& W 3=\frac{3}{1+2+3}=0.50000000
\end{aligned}
$$

Kemudian dilakukan perhitungan vektor $\mathrm{s}$ (hasil sementara), sebelum dihitung menjadi vektor $\mathrm{v}$ (hasil akhir). Adapun perhitungannya menggunakan rumus 2 .

$$
\begin{aligned}
S_{1} & =\left(90^{0.1666666667}\right) x\left(80^{0.333333333}\right) x\left(3.5^{0.5}\right) \\
& =17.06492705 \\
S_{2} & =\left(75^{0.1666666667}\right) x\left(90^{0.333333333}\right) x\left(3.8^{0.5}\right) \\
& =17.93974141 \\
S_{3} & =\left(90^{0.1666666667}\right) x\left(70^{0.333333333}\right) x\left(3.3^{0.5}\right) \\
& =
\end{aligned}
$$

15.84881277

$$
\begin{aligned}
S_{4} & =\left(70^{0.1666666667}\right) x\left(80^{0.333333333}\right) \times\left(3.4^{0.5}\right) \\
& =16.12943399
\end{aligned}
$$

$$
\begin{aligned}
S_{5} & =\left(90^{0.1666666667}\right) \times\left(75^{0.333333333}\right) \times\left(3.5^{0.5}\right) \\
& =16.70173268
\end{aligned}
$$

Selanjutnya mencari vektor $\mathrm{v}$ yang merupakan hasil akhir perangkingan menggunakan rumus 3 .

$$
\begin{aligned}
& V_{1}=\frac{17.06492705}{83.6846479}=0.203919446 \\
& V_{2}=\frac{17.93974141}{83.6846479}=0.214373148 \\
& V_{3}=\frac{15.84881277}{83.6846479}=0.189387339 \\
& V_{4}=\frac{16.12943399}{83.6846479}=0.192740657 \\
& V_{5}=\frac{16.70173268}{83.6846479}=0.19957941
\end{aligned}
$$

Berdasarkan perhitungan tersebut, didapatkan V2 memiliki nilai tertinggi, sehingga Shania yang terpilih mendapatkan beasiswa lokal prodi D3 Manajemen Informatika Unmer Madiun.

Sistem yang telah dibangun, kemudian diuji menggunakan metode blackbox. Untuk butir pengujiannya antara lain halaman beranda, halaman login, halaman data kriteria, input data kriteria, halaman data alternatif, input data alternatif, halaman hasil seleksi, cetak hasil, dan logout. Dari pengujian sembilan butir uji, didapatkan hasil 100\% berhasil.

\section{KesimpUlan}

Berdasarkan hasil pengujian yang telah dilakukan pada sistem pendukung keputusan pemilihan mahasiswa penerima beasiswa lokal Prodi D3 Manajemen Informatika Unmer Madiun menggunakan metode Weighted Product, maka dapat disimpulkan bahwa sistem dapat berjalan dengan baik karena memiliki tingkat keberhasilan sebesar $100 \%$ setelah dilakukan pengujian menggunakan metode Black Box.

\section{DAFTAR PUSTAKA}

[1] N. Nurjannah, Z. Arifin, dan D. M. Khairina, "SEPEDA MOTOR DENGAN METODE WEIGHTED PRODUCT," vol. 10, no. 2, hal. 2-6, 2015.

[2] H. R. Hatta, M. Rizaldi, dan D. M. Khairina, "Penerapan Pen erapan Metode Weighted Product U ntuk Pemilihan Lokasi L ahan Baru Pemakaman Muslim Dengan Visualisasi Google Maps," vol. 2, no. 3, hal. 85-94, 2016.

[3] D. C. Yoni dan H. Mustafidah, "Penerapan Metode WP ( Weighted Product ) Untuk Pemilihan Mahasiswa Lulusan Terbaik di Fakultas Teknik Universitas Muhammadiyah Purwokerto ( Application of WP ( Weighted Product ) Method For Selection of Best Graduate Students In The 
Engineering Faculty of," vol. IV, hal. 22-27, 2016.

[4] D. M. Khairina, D. Ivando, dan S. Maharani, "Implementasi Metode Weighted Product Untuk Aplikasi Pemilihan Smartphone Android,” vol. 8, no. 1, hal. 1-8, 2016.

[5] J. Sayyad Shirabad, S. Wilk, W. Michalowski, dan K. Farion, "Implementing an integrative multi-agent clinical decision support system with open source software," J. Med. Syst., vol. 36, no. 1, hal. 123-137, 2012.

[6] M. Arsyad, "Sistem Pendukung Keputusan Untuk Seleksi Calon Ketua Badan Eksekutif Mahasiswa ( BEM ) STMIK Banjarbaru Dengan Metode Weighted Product ( WP ) Muhammad Arsyad," vol. 4, no. 1, hal. 51-59, 2016.

[7] R. Benbenishty dan R. Treistman, "The development and evaluation of a hybrid decision support system for clinical decision making: The case of discharge from the military," Soc. Work Res., vol. 22, no. 4, hal. 195-204, Des 1998.

[8] N. A. Syafitri, A. P. Dewi, J. T. Informatika, F. Teknik, dan U. H. Oleo, "Penerapan metode," vol. 2, no. 1, hal. 169-176, 2016.

[9] I. Kekytė dan V. Stasytytè, "Comparative Analysis of Investment Decision Models," Moksl. - Liet. ateitis, vol. 9, no. 2, hal. 197-208, 2017.

[10] M. Jalil, Abdul; Ningrum, Ika; Muchtar, "Spk pemberian kredit menggunakan metode," vol. 3, no. 1, hal. 173-180, 2017.

[11] H. Mustafidah dan H. N. Hadyan, "Sistem Pendukung Keputusan Penentuan Mahasiswa Berprestasi di Universitas Muhammadiyah Purwokerto Menggunakan Metode Weighted Product ( WP ) ( Decision Support System of Excellent Student Determination in Universitas Muhammadiyah Purwokerto Using Weighted," vol. V, hal. 51-61, 2017.

[12] A. P. Widyassari dan T. Yuwono, "Perbandingan Analytical Hierarchy Process dan Fuzzy Mamdani untuk Sistem Pendukung Keputusan Pemilihan Rumah di Daerah Cepu," Res. Comput. Inf. Syst. Technol. Manag., vol. 1, no. 2, hal. 50-54, Okt 2018.

[13] A. Suhartanto dan R. Pamungkas, "Implementasi Sistem Informasi Dalam Perbaikan Kualitas Laporan Keuangan Pada CV. Tri Agri," Res. Comput. Inf. Syst. Technol. Manag., vol. 1, no. 2, hal. 46-49, Okt 2018. 